\title{
鼓室型先天性真珠腫症例と文献的考察
}

\author{
近藤 玲子・川端五十鈴
}

\section{Congenital Cholesteatoma of the Tympanum; Report of a Case and Review of the Literature}

\author{
Reiko Kondo and Isuzu Kawabata \\ (Saitama Medical Center, Saitama Medical School)
}

\begin{abstract}
A 5-year-old boy with congenital cholesteatoma in the mesotympanum also had external abnormalities on the involved side: bat ear and low set ear. The cholesteatoma seemed to originate from the undersurface of the processus cochleariformis and the tendon of the tensor tympani muscle.

We reviewed 208 reported cases of congenital cholesteatoma of the middle ear.

In 28 cases it originated from the tympanic isthmus, as formerly reported. The incidence in boys was twice as high as in girls. A relatively high incidence of congenital malformations was found. These findings suggest that congenital cholesteatoma is the result of an embryologic error.
\end{abstract}

Key words : congenital cholesteatoma, middle ear, embryology

はじめに

先天性真珠腫は早期には症状がそしく，難聴， 二次感染による耳漏, 顔面神経麻痺などが出現 してから受診するてとが多い. しかし学校検診, 小児科における耳鏡検査で偶然に発見されるこ とああり，早期例の報告は徐々に増えてきてい る. 我々はサジ状突起, 鼓膜張筋腱の部位より 発生したと考えられる，比較的早期の先天性真 珠腫の一症例を経験したので，本症の臨床所見， 発生原因について文献的考察を加えて報告する。

\section{症例}

患者： 5 歳, 男子.

家族歴・既往歴：特記すべきととなし.

現病歴：1988年 6 月に小児科で，左鼓膜のツ チ骨柄の前方に白色の变化があるのを指摘され，
その後の経過観察で消失しないため，1989年 4 月15日当科を紹介された。 耳痛, 耳漏, 中耳炎 の既往はない.

初診時所見：左の耳介低位，立ち耳（図 1 ) を認め，左鼓膜の内側で，上方 $3 / 4$ に白色塊が 透見された．聴力は正常であり，ティンパノグ ラムは $\mathrm{A}$ 型であった. 平衡機能, 温度眼振とあ に正常であった。X線では乳突蜂巣の発育は良 好で異常陰影は見られず，側頭骨 C T 亿て鼓膜 に接する中鼓室の軟部陰影を認めた（図2). 以上の所見より先天性真珠腫を疑い，5 月17日 手術を施行した。

手術所見：鼓膜外耳道皮膚弁を翻転すると， ツチ骨柄を中心として中鼓室の前後に及ぶ真珠 腫が存在した．真珠腫は鼓膜と接するものの癒

埼玉医科大学総合医療センター耳鼻咽喉科 


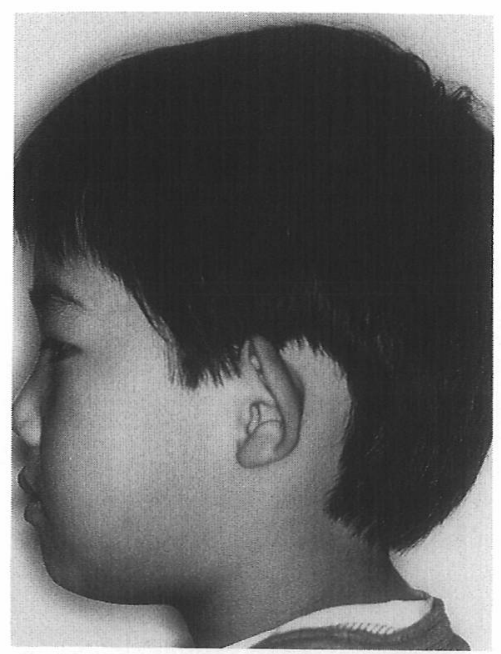

図1 左の立ち耳，耳介低位を認める。

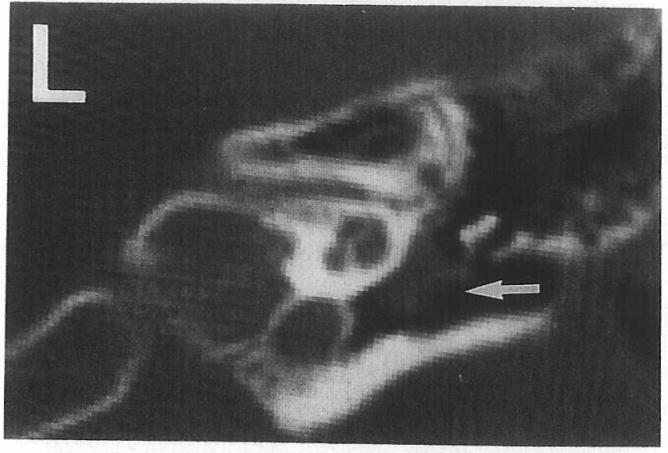

図 2 側頭骨 coronal CT ↔中鼓室内の軟部陰影
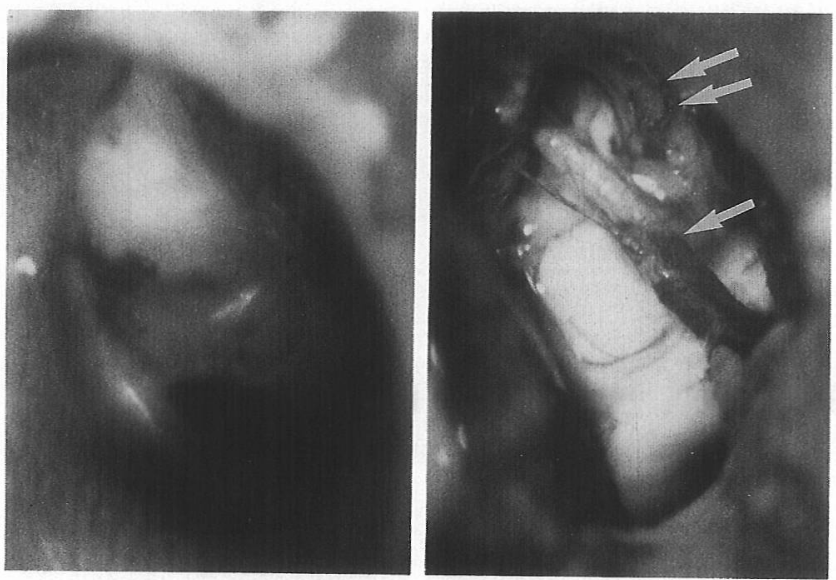

図 3 術中写真

真珠腫は鼓膜と接するが崅着はない。

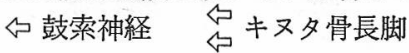

着は見られなかった（図３）。また，真珠腫に は分節があるが一房性であり， matrix は通常の 真珠腫より脆弱であった. 中耳に炎症所見, 奇 形は無く，また，耳小骨の欠損屯無く，耳小骨 連鎖は正常に保たれていた。真珠腫は中鼓室前 後を占めていたが上鼓室には進展して扔らず， その付着状態から，サジ状突起，鼓膜張筋腱の 下方より発生していると考えられた（図 4). 真珠腫を en block に摘出し, 鼓室形成術 I 型

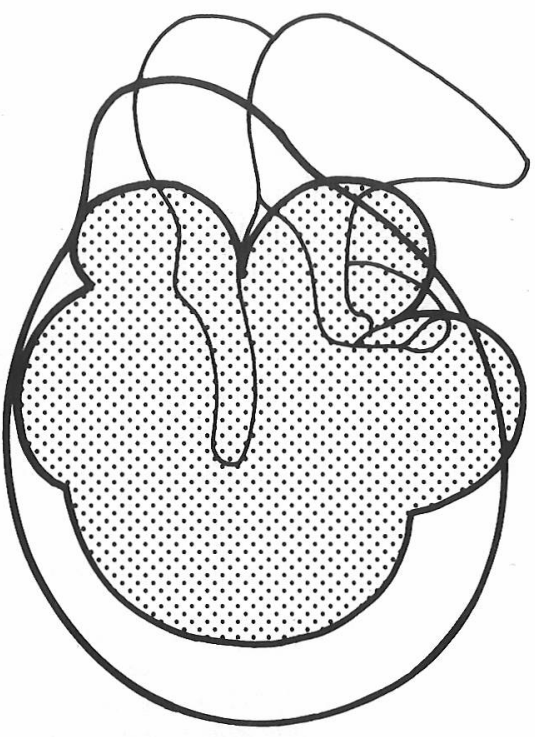

図 4 真珠腫の進展範囲 
とした，術後 7 カ月たった現在，鼓膜は正常の 外観を呈し，再発の様子はない.

\section{考察}

先天性真珠腫の発生部位, 臨床症状, 発生原 因を文献的に検討した．先天性真珠腫はその部 位により，(1)中耳型：鼓室型，鼓室十乳突洞型， 乳突洞型，(2)錐体型に大別される. 検討の対象 は中耳型真珠腫の鼓室型, 鼓室＋乳突洞型に限 った．乳突洞型は症例が 3 例と少なく, 錐体型 真珠腫は範囲が広範なため, 発生部位を検討す るのが困難であり除外した。 また，既往に鼓膜 切開, チュービングを施行した症例は鼓膜内真 珠腫を形成する可能性がある1) ので除外し，鼓 膜に穿孔のある症例，鼓膜内真珠腫屯対象加ら はずした。しかし，中耳炎に関しては，3歳ま でに $71 \%$ が 1 回，またはそれ以上罹患している との報告があり ${ }^{2)}$ ，対象に含めた。

1 ）性別・年齢

中耳に発生する先天性真珠腫は我々が検索し た範囲では，1988年までに国内，国外で 208 例 (dermoid 2 例) 報告されており，そのうち両側 は 5 例 (dermoid 1 例) であった。年齢は 5 歳 ７8歳，平均11歳之小児に多く，男女比は 2 対 1 で男性に多く見られた。左右差は認められな かった.

また, 頸部血管腫, 松果体未分化細胞腫, 尿 道下裂，幽門狭窄，股関節脱臼，先天性耳瘻孔
(患側), 副耳 (患側), abscence of the septum canalis musculotubalis が各々 1 例ずつ，耳小 骨奇形（キ又タ骨，アブミ骨の欠損 4 例，ッチ 骨柄の変形 1 例), 内耳奇形 1 例, fetal distress 3 例之合計17例に何らかの先天異常が見られた.

2) 初発症状・鼓膜所見

初発症状としては難聴が56例 (43\%) と最も 多く，次に，無症状で，偶然に鼓膜の白色塊を 発見された症例が42例（32\%）見られた（表1). また, 耳鼻咽喉科で発見される以外にも学校検 診で難聴を指摘された症例が27例，小坚科で鼓 膜の異常所見として発見された症例が27例見ら れた．鼓膜所見としては，鼓膜の白色塊が80例 （60\%）と最む多く，正常31例（23\%）であった。 滲出性中耳炎が合併していた症例は少なく，5 例（4\%）であった（表 2).

\section{3 ) 真珠腫の発生部位}

中鼓室内に限局し, 真珠腫の部位が明瞭な症 例は95例で，前上象限（以下 $\mathrm{ASQ}$ と略す）に あるあの 35 例 $(37 \%)$, 後上象限 (以下 PSQ と略す）13例（14\%）と ASQ に多く見られた （表 3 ）. 鼓室前方に存在する真珠腫41例中，正 常聴力が 31 例, 耳小骨正常 22 例であるのに対 し，鼓室後方より発生した真珠腫54例では33例 に何らかの伝音難聴があり，キヌタ骨，ッチ 骨のカリエス，消失を伴う症例が大半を占めて いた．中耳炎の既住に関しては鼓室前方にある
表 1

\begin{tabular}{l|c}
\hline \multicolumn{1}{c|}{ 初発症状 } & 例 \\
\hline 難恥 & 56 \\
鼓膜の白色塊 & 42 \\
急性中耳炎 & 9 \\
耳痛 & 6 \\
顔面神経麻㾅 & 6 \\
耳漏 & 4 \\
眩暈 & 3 \\
滲出性中耳炎 & 2 \\
耳閉感 & 2 \\
耳後部腫脹 & 1 \\
\hline \multicolumn{1}{c}{ 計 } & 131
\end{tabular}

表 2

\begin{tabular}{l|c}
\hline \multicolumn{1}{c|}{ 鼓膜所見 } & 例 \\
\hline 鼓膜の白色塊 & 80 \\
正常 & 31 \\
鼓膜の膨隆 & 7 \\
鼓膜の混濁 & 6 \\
滲出性中耳炎 & 5 \\
急性中耳炎 & 3 \\
鼓膜の肥厚 & 1 \\
\hline \multicolumn{1}{c}{ 計 } & 133
\end{tabular}


あのと，後方にあるあのの間に頻度の差は見ら れなかった，但し，乳突蜂巣の発育は鼓室前方 にある症例では良好18例中陰影のある症例 1 例， 不良 1 例に対し，後方にあるあのでは良好12例 中 4 例に陰影があり，不良な症例が 8 例であっ た. 先天性真珠腫が isthmus を塞ぎ，乳突蜂巣 の発育に影響を及ぼす可能性むあるが，報告例 の中には後天性症例が含まれる可能性が考えら れた。 また，真珠腫が発生している部位の記載 のある28例中，サジ状突起，ツチ骨頸，鼓膜張 筋腱付近が 24 例（両側 2 例），卵円空小窩 3 例， キヌタ・アブミ関節，アブミ骨筋腱が各々 1 例 であった (表 4 $)^{3) ~ 99 .}$

\section{4 ）先天性真珠腫の発生原因}

真珠腫の発生に関しては Rüedi に代表され る migration theory がある。1957年彼は胎児， 生後早期の小児の側頭骨で, 鼓膜前上方に接す る外耳道上皮の増殖を観察し，炎症によって Shrapnell's membrane に接する外耳道上皮, または Shrapnell's membrane の上皮の増殖, 遊走がおこり真珠腫が形成されると仮定した ${ }^{10)}$. 1959年にはモルモットの鼓膜内側にタルクとフ ィブリンを塗布し炎症を起こすととで，鼓膜上 皮の基底細胞の増殖が鼓室内の肉芽組織に侵入 し，真珠腫が形成されるのを観察している ${ }^{11)}$. 同様に Fernândez らも炎症により基底層の細 胞増殖が起こるのを動物実験で証明し，鼓膜の 穿孔が無くても真珠腫が形成されるとした ${ }^{12)}$.
Sobol ${ }^{133}$ らは, 鼓膜が正常な小児の真珠腫15例中 13例で反復性の中耳炎が見られたため，正常な 鼓膜の真珠腫が，炎症による後天性の真珠腫で ある可能性を示唆した。また, Schwartz ら ${ }^{14)}$ は 小児における鼓膜穿孔の無い真珠腫34例の内， 中耳炎の既往が無い症例は 6 例のみであり，鼓 膜切開，チュービングを施行されている症例む 多く，鼓膜が正常な場合の真珠腫の中には後天 性の真珠腫が含まれる可能性があると報告して いる．今回の文献例の統計では, PSQ に発生し た真珠腫では乳突蜂巣の発育が不良な症例が多 く，後天性の真珠腫が含まれる可能性が考えら れる，しかし，先天性真珠腫が炎症の関与の無 い 5 週の乳児にも見られ，中鼓室の好発部位が ASQ であることは，後天性真珠腫が PSQ 好発 部位であるのと相反し， migration theory のみ では鼓膜穿孔の無い場合の真珠腫の発生機序を

表 4

\begin{tabular}{|c|c|c|c|c|}
\hline 年 & 報告者 & 真珠腫の発生部位 & 例 & \\
\hline 1988 & Levenson & ッチ骨䅡, 鼓膜張筋腱 & 8 & \\
\hline 1987 & Litman & ッチ骨頚, サジ状突起 & 1 & （両側例） \\
\hline 1987 & 荒木 & 卵円空小窝 & 3 & \\
\hline 1986 & 喜多村 & キヌタ・アブミ関節 & 1 & \\
\hline 1986 & Levenson & ツチ骨䅡, 鼓膜張筋腱 & 13 & \\
\hline 1983 & Wehrs & 鼓膜張筋腱 & 1 & \\
\hline 1978 & Wingert & ツチ骨頚 & 1 & (両側例) \\
\hline & & 計 & 28 & \\
\hline
\end{tabular}

表 3

\begin{tabular}{|c|c|c|c|c|c|c|c|}
\hline 部 位 & 例 & 聴 オ & & \multicolumn{2}{|c|}{ 耳小骨の破懐 } & \multicolumn{2}{|c|}{ 乳突篗宩の発育 } \\
\hline ASQ & 35 & \multirow{4}{*}{\multicolumn{2}{|c|}{$\begin{array}{c}\text { 正常 }-31 \\
30 \sim 33 \mathrm{~dB}-1\end{array}$}} & \multirow{4}{*}{$\begin{array}{l}\text { 正常 } \\
\text { キヌ夕骨豆状乫起 } \\
\text { のカリエス }\end{array}$} & \multirow{4}{*}{$\begin{array}{l}-22 \\
-3\end{array}$} & 良 & 不良 \\
\hline$A S Q+A I Q$ & 1 & & & & & \multirow{3}{*}{$\begin{array}{c}18 \\
\left(\begin{array}{c}18 \\
1\end{array}\right)\end{array}$} & \multirow[t]{3}{*}{1} \\
\hline$A I Q$ & 1 & & & & & & \\
\hline ASQ + attic & 4 & & & & & & \\
\hline PSQ & 13 & \multirow{4}{*}{\multicolumn{2}{|c|}{$\begin{array}{l}\text { 正常 } \quad-2 \\
\text { 25 70dBO } \\
\text { 伝音䧳 }-33\end{array}$}} & \multirow{4}{*}{\multicolumn{2}{|c|}{ 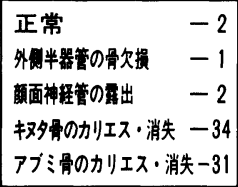 }} & \multirow{4}{*}{ 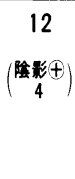 } & \multirow[t]{4}{*}{8} \\
\hline $\mathrm{PSQ}+\mathrm{PIQ}$ & 3 & & & & & & \\
\hline PSQ+attic & 9 & & & & & & \\
\hline PSQ mastoid & 29 & & & & & & \\
\hline
\end{tabular}


できない.

1983年に DeSa は72例の乳児の中耳内に27例 で羊膜細胞由来の扁平上皮化生を認め, 特に扁 平上皮の大きなものはキヌタ・アブミ関節に多 く見られたと報告している ${ }^{15)}$ 。乙の報告の症例 全部が肺炎に罹患し，経鼻插管，酸素吸入を受 けており，鼓室内に炎症所見が見られた. 同様 に Northrop ら ${ }^{16)}$ は乳生児, 乳児の側頭骨内 に角化した羊膜細胞を観察し，乙れが先天性真 珠腫の発生に関与することを述べている。 また Sadè ら ${ }^{17}$ は，中耳の粘膜は化生能力があり， 炎症により真珠腫となると提唱した。 以上の metaplasia theory による発生機序では何らか の炎症が関与しており，炎症の全く認められな い先天性真珠腫をこの説で説明するのは困難で ある。

今回の統計では男性 2 亿対し女性 1 と有意の 差を認めた．外耳道閉鎖症，唇裂などの先天性

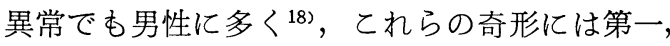
第二鰓弓，第一鰓溝が関与している. Aimi ${ }^{19)}$ は 胎児の外耳道上皮板は乳頭状増殖能があり，乙 の変化が鼓室輪によるストップシグナル以前に 生ずると，外耳道上皮板が tympanic isthmus の間葉組織に侵入する可能性があるとした。実 際に16週半の胎児で外耳道上皮板が内腔化し， アブミ骨後方で乳頭状増殖をおこしているのを 提示している．また，isthmus は第一，第二鰓 弓の接合部であり, 鼓膜張筋腱, 顔面神経水平 部，鼓索神経で囲まれる空間である．今回の統 計では, 先天性真珠腫の発生部位の報告は全て isthmus に含まれており，Aimi の説を指示す る所見と思われる。 さらに Michaels ${ }^{20)}$ は34〜 77日の胎児標本20例中，16例の連続切片で epidermoid formation (EF) を認め，33週以後には 消失していることを確認した。 EF は第一鰓溝 の外胚葉成分が第一咽頭囊に移動し形成され， 中耳と鼓膜の形成を誘導する器官であると推定 するとともに，EF は中耳腔形成後，鼓室上前 方に位置し消失するが，遺残した場合に先天性 真珠腫を形成する可能性があるとした. Leven- $\operatorname{son}^{3)}$ は鼓膜張筋腱 屯鼓室上前方に位置し，先 天性真珠腫がこの部位より発生することが多く みられることより， Michaels の説を支持して いる. Teed ${ }^{21)}$ も Michaels に先立って同様の器 官を胎児の鼓室内に認め, epibranchial organ の遺残が先天性真珠腫の形成に関与していると 結論し，キヌタ骨の内側に上皮組織が存在する 5 力月半の胎児の標本を報告している.

先天性真珠腫の統計では，奇形の合併率が高 く, 何らかの形成異常が関与していると推察さ れた. 我々の症例は耳介低位, 立ち耳があり, 第一, 第二鰓弓, 第一鰓溝の発生過程の異常が 真珠腫の形成に関与している可能性が推察され た. さらにサジ状突起, 鼓膜張筋腱の部位より 発生したと考えられ, Aimi, Michaels らの embriologic theory を支持する症例と思われた。

\section{まとめ}

先天性鼓室型真珠腫の一症例を報告し，本症 の臨床所見, 発生原因について文献的に考察し, 併せて報告例の真珠腫発生に第一，第二鰓弓， 第一鰓溝の発生過程の異常が関与している可能 性を示した。

本論文の要旨は，第17回日本臨床耳科学会総会（平 成元年10月）でロ演した.

\section{文献}

1) Söderberg O, Hellströme $S$ and Stenfors LE : Structural changes in the tympanic membrane after repeated tympanostomy tube insertion. Acta Otolaryngol $102: 382 \sim 390,1986$.

2 ) Teele DW, Klein JO and Rosner BA : Epidemiology of otitis media in children. Ann Otol Rhinol Laryngol $89:$ 5 6, 1980.

3) Levenson MJ, Michaels L, Parisier SC, et al : Congenital cholesteatomas in childrn; an embryologic correlation. Laryngoscope $98: 949 \sim 955$, 1988.

4) Litman RS, Parisier SC, Hausman SA, et al : Bilateral congenital cholesteatoma; a cause or result of chronic otitis media with effusion? Am J Otol 8 : 426 431, 1987.

5 ）荒木伸彦, 山下公一, 堤内邦彦, 他 : 先天真珠腫 
症例の検討. 臨床耳科 $14: 98,1987$.

6 ）喜多村健, 大西裕美子, 横小路雅文 : 先天性中耳 真珠腫. 日耳鼻 $89: 1562,1986$.

7) Levenson MJ, Parisier SC, Chute P, et al: A review of twenty congenital cholesteatoma of the middle ear in children. Otolaryngol Head Neck Surg $94: 560 \sim 567,1986$.

8) Wehrs RE : The sleeve autograft in congenital cholesteatoma. Ann Otol Rhinol Laryngol 92 : 571 576, 1983.

9) Wingert RH, McCurdy JA and Hays LL : Cholesteatoma; congenital and acquired. Milit Med $143: 714 \sim 719,1978$.

10) Rüedi $L$ : Pathogenesis and treatment of cholest eatoma in chronic suppuration of the temporal bone. Ann Otol Rhinol Laryngol $66: 283 \sim 305$, 1957.

11) Rüedi $L$ : Cholesteatoma formation in the middle ear in animal experiments. Acta Otolaryngol $50: 232 \sim 242,1959$.

12) Fernândez $C$ and Lindsay JR : Aural cholesteatoma; experimental observations. Laryngoscope $70: 1119 \sim 1141,1960$.

13) Sobol SM, Reichert TJ, Faw KD, et al : Intramembranous and mesotympanic cholesteatomas associated with an intact tympanic membrane in children. Ann Otol 89 : 312 317, 1980.

14) Schwartz RJ, Grundfast KM, Feldman B, et al : Cholesteatoma medial to an intact tympanic membrane in 34 young children. Pediatrics 74 :
236 340, 1984.

15) Desa DJ : Mucosal metaplasia and chronic inflammation in the middle ear of infants recieving intensive care in the neonatal period. Arch Dis Child 58 : 24 28, 1983.

16) Northrop C, Piza J and Eavey RD : Histological observations of amniotic fluid cellular content in the ear of neonates and infants. Int J Pediatr Otorhinolaryngol $11:$ 113 127, 1986.

17) Sadé J, Babiacki A and Pinkus G: The metaplastic and congenital origin of cholesteatoma. Acta Otolaryngol $96: 119 \sim 129,1983$.

18) Jafek BW, Nager GT, Strife J, et al : Congenital aural atresia; an analysis of 311 cases. Trans Am Acad Opthalmol Otolaryngol 80 : 588 595, 1975.

19) Aimi $K$ : Role of the tympanic ring in the pathogenesis of congenital cholesteatoma. Laryngoscope $93: 1140 \sim 1146,1983$.

20) Michaels L : Evolution of the epidermoid formation and its role in the development of the middle ear and tympanic membrane during the first trimester. J Otolaryngol $17: 22 \sim 28,1988$.

21) Teed RW : Cholesteatoma verum tympani; its relationship to the first epibranchial placode. Arch Otolaryngol 24 : 455 474, 1936.

$\left(\begin{array}{l}\text { 原稿受付 : 平成元年 } 11 \text { 月 } 9 \text { 日 } \\ \text { 原稿採択 : 平成 } 2 \text { 年 } 2 \text { 月 } 16 \text { 日 } \\ \text { 別刷請求先 }: \text { 近藤玲子 } \\ \text { 干 } 350 \text { 埼玉県川越市鴨田辻道町 } 1981 \\ \text { 埼玉医科大学総合医療センター }\end{array}\right)$

